\title{
Retrospective Ecotoxicological Data and Current Information Needs for Terrestrial Vertebrates Residing in Coastal Habitat of the United States
}

\author{
B. A. Rattner, ${ }^{1}$ K. M. Eisenreich, ${ }^{1}$ N. H. Golden, ${ }^{2}$ M. A. McKernan, ${ }^{1}$ R. L. Hothem, ${ }^{3}$ T. W. Custer ${ }^{4}$ \\ ${ }^{1}$ U. S. Geological Survey, Patuxent Wildlife Research Center, Beltsville Laboratory, c/o BARC-East, Building 308, 10300 Baltimore Avenue, Beltsville, \\ Maryland 20705, USA \\ ${ }^{2}$ U.S. Fish and Wildlife Service, Division of Environmental Quality, 4401 N. Fairfax Drive, Arlington, Virginia 22203, USA \\ ${ }^{3}$ U.S. Geological Survey, Western Ecological Research Center, 6924 Tremont Road, Dixon, California 95620, USA \\ ${ }^{4}$ U. S. Geological Survey, Patuxent Wildlife Research Center, Upper Midwest Environmental Sciences Center, 2630 Fanta Reed Road, La Crosse, \\ Wisconsin 54603, USA
}

Received: 15 September 2004/Accepted: 27 February 2005

\begin{abstract}
The Contaminant Exposure and Effects-Terrestrial Vertebrates (CEE-TV) database was developed to conduct simple searches for ecotoxicological information, examine exposure trends, and identify significant data gaps. The CEETV database contains 16,696 data records on free-ranging amphibians, reptiles, birds, and mammals residing in estuarine and coastal habitats of the Atlantic, Gulf, and Pacific coasts, Alaska, Hawaii, and the Great Lakes. Information in the database was derived from over 1800 source documents, representing 483 unique species (about 252,000 individuals), with sample collection dates spanning from 1884 to 2003. The majority of the records contain exposure data (generally contaminant concentrations) on a limited number $(n=209)$ of chlorinated and brominated compounds, cholinesterase-inhibiting pesticides, economic poisons, metals, and petroleum hydrocarbons, whereas only $9.3 \%$ of the records contain biomarker or bioindicator effects data. Temporal examination of exposure data provides evidence of declining concentrations of certain organochlorine pesticides in some avian species (e.g., ospreys, Pandion haliaetus), and an apparent increase in the detection and possibly the incidence of avian die-offs related to cholinesterase-inhibiting pesticides. To identify spatial data gaps, 11,360 database records with specific sampling locations were combined with the boundaries of coastal watersheds, and National Wildlife Refuge and National Park units. Terrestrial vertebrate ecotoxicological data were lacking in $41.9 \%$ of 464 coastal watersheds in the continental United States. Recent (1990-2003) terrestrial vertebrate contaminant exposure or effects data were available for only about half of the National Wildlife Refuge and National Park units in the geographic area encompassed by the database. When these data gaps were overlaid on watersheds exhibiting serious water quality problems and/or high vulnerability to pollution, 72 coastal watersheds, and 76 National Wildlife Refuge and 59 National Park
\end{abstract}

Correspondence to: B. A. Rattner; email: Barnett_Rattner@USGS. gov units in the continental United States were found to lack recent terrestrial vertebrate ecotoxicology data. Delineation of data gaps in watersheds of concern can help prioritize monitoring in areas with impaired water quality and emphasize the need for comprehensive monitoring to gain a more complete understanding of coastal ecosystem health.

The Biomonitoring of Environmental Status and Trends (BEST) Program of the U.S. Geological Survey (USGS) (1) assesses the exposure and effects of environmental contaminants on select species and habitats throughout the United States, (2) conducts research and synthesis activities that provide biomonitoring methods for field application, and (3) supports the development of methods and tools to assist the U.S. Department of the Interior in assessing chemical threats to species and lands under its stewardship (Zylstra 1994; BEST 2003). Although there are many ecotoxicological monitoring programs that focus on aquatic species and habitats (Breckenridge et al. 2003), the National Contaminant Biomonitoring Program (NCBP) of the U.S. Fish and Wildlife Service (US FWS) has been the only large-scale effort that has examined contaminant exposure in terrestrial vertebrates in the United States. The NCBP was discontinued in 1990 for a number of reasons (NRC 1995), including the decline in concentrations of organochlorine pesticides and total PCBs in mallard (Anas platyrhynchos) and black duck (A. rubripes) wings and European starling (Sturnus vulgaris) carcasses (Schmitt and Bunck 1995). However, organochlorine contaminants, metals, and new pollutants continue to pose hazards to terrestrial vertebrates at many geographic scales (i.e., small hazardous waste sites to entire watersheds). To address this hazard, the BEST Program seeks to identify critical data gaps through the retrospective compilation and analysis of ecotoxicological data, followed by active monitoring of terrestrial vertebrates at high priority sites and regions, as funding permits. 
In 1996, efforts were initiated to develop and compile a "Contaminant Exposure and Effects-Terrestrial Vertebrates" (CEE-TV) database (Rattner et al. 2000). Initially, work was focused on terrestrial vertebrates found in Atlantic estuarine habitats, but the geographic scope of the database has since been expanded to include estuarine and coastal habitat along the Gulf and Pacific coasts, Alaska, Hawaii, and the shoreline and islands on the Laurentian Great Lakes. The database became accessible in searchable format on the World Wide Web (http://www.pwrc.usgs. gov/contaminants-online) in 1999. The CEE-TV database has been used by many biologists and natural resource managers (Russom 2002) to conduct simple searches for exposure and biological effects information for a given species or location, identification of temporal contaminant exposure trends, data gap analyses for National Wildlife Refuge and National Park units, and ranking of terrestrial vertebrate ecotoxicological information needs based on data density and water quality problems. For example, there are no ecotoxicological data on terrestrial vertebrates from 1990 to 2000 (Cohen et al. 2003) from 15 of the 136 Atlantic and Florida-Gulf coast watersheds classified by the U.S. Environmental Protection Agency (US EPA) Index of Watershed Indicators (IWI) (US EPA 1997a, 2000) as having water quality problems or high vulnerability to pollution. Furthermore, 59 of 132 (44.6\%) National Wildlife Refuge and National Park units in watersheds of concern lack terrestrial vertebrate exposure and effects data for this same region and time period.

Herein we expand on our initial evaluation of the database (Rattner et al. 2000), with special emphasis on spatial and temporal data gaps in measures of contaminant exposure for terrestrial vertebrates residing in the Atlantic, Gulf, and Pacific coasts, Alaska, Hawaii, and the Great Lakes. Our intent is to provide scientists and natural resource managers essential information that will aid in the prioritization of contaminant biomonitoring in watersheds, and units of the National Wildlife Refuge System and National Park System.

\section{Materials and Methods}

\section{Data Acquisition and Database Design}

Retrospective contaminant exposure and effects data for free-ranging terrestrial vertebrates residing in U.S. estuarine and coastal habitat were identified and compiled using scientific literature search tools (e.g., Wildlife Review, BIOSIS, TOXLINE, AGRICOLA), by examining various databases (e.g., US EPA Ecological Incident Information System, US FWS Environmental Contaminant Data Management System, USGS National Wildlife Health Center Mortality Database), and through communication with 480 scientists in federal and state agencies, conservation organizations, and academic institutions. Source documents were reviewed to identify data collected in estuarine and coastal drainages, and, unless obvious flaws in data quality were apparent, information was coded for database entry. All data were referenced with geographic collection coordinates, and if absent from the source document, coordinates were assigned based on the location description using MapExpert version 2.0 (DeLorme Mapping, Freeport, ME, USA), USGS Geographic Names Information System (http://geonames.usgs.gov/gnishome.html), or the Cana- dian Geographical Names website (http://geonames.nrcan.gc.ca/ index_e.php). If samples were collected across an entire county, the coordinates of the county seat were assigned to the record. If the samples were collected across an entire state or the collection location in the state was not specified, the coordinates of the state capital were assigned to the record. Data were compiled in a 118-field database in Microsoft Access 2000 version 9.0 (Microsoft Corp., Redmond, WA, USA) with information describing taxonomy, collection date, study location, geographic coordinates, sample matrix, contaminant concentration, biomarker or bioindicator response, and source of information. Additional details of the CEE-TV database have been published (Rattner et al. 2000) and are available on the Internet (http://www.pwrc.usgs.gov/contaminants-online).

\section{Descriptive and Geographic Analyses}

The CEE-TV database was sorted and queried for phylogenetic, temporal, spatial, and contaminant exposure and response patterns using search features of Access. Maps of record locations were created using ArcGIS 8.2 (Environmental Systems Research Institute, Inc., Redlands, CA 2000) geographic information systems software, and overlaid on boundary maps of watersheds (defined by USGS 8digit Hydrologic Unit Codes), and National Wildlife Refuge and National Park units.

Spatial information gap analyses were conducted by overlaying locations of CEE-TV records on these maps. To avoid the potential bias of records with coordinates assigned to a county seat or state capital, only records with known collection coordinates were used in geospatial analyses. Data gaps were defined as recent if there are no records with data collected from 1990 to 2003; data gaps were defined as historic if there are no records with data prior to 1990 . To account for possible imprecision and uncertainty of sampling coordinates, maps with a 1-km buffer were created around each National Wildlife Refuge and National Park property boundary, and to account for animal movement, 10-km buffers were used around each of these management units.

In order to identify the information data gaps that are of greatest concern, the buffered National Wildlife Refuge and National Park units were overlaid on the IWI (US EPA 1997a, 2000). The IWI classifies watershed water quality from "better" to "more serious" as well as watershed vulnerability (i.e., potential for discharges and other stressors to affect water quality) from "low" to "high." The IWI rankings were joined by Hydrologic Unit Codes to the watershed database, creating a map identifying watersheds of concern (i.e., IWI classifications of more serious water quality problems and/or high vulnerability to pollution). Each of the management units that intersected watersheds of concern was placed into a separate map for further information gap analysis.

\section{Results and Discussion}

\section{Source Documents and Composition of the CEE-TV Database}

As of December 2003, the CEE-TV database contained a total of 16,696 records. Many of the reference sources contained data from multiple sample matrices collected from numerous sampling locations, and more than one species; thus a single source document frequently generated many geo-referenced records. The 1849 source documents used for this database included 718 published journal articles, 63 peer-reviewed conference proceedings or books, 11 abstracts from scientific 
meetings, 20 Master's thesis or Doctoral dissertation documents, 854 necropsy reports, 167 reports or unpublished manuscripts, and 16 records from other databases.

The number of organisms per record ranged from 1 to 37,590 , with about $50 \%$ of the records containing information on multiple individuals. Because several sample matrices were often quantified in a single organism, and occasionally pooled tissue samples were analyzed, the total number of unique individuals in the database is estimated to be 252,000. Fiftyfive different sample matrices were quantified, with the most common matrix being egg content, followed, in decreasing order, by liver, brain, carcass, muscle, kidney, adipose, blood, wing, feather, eggshell, gizzard, gastrointestinal tract, and hair.

The geographic coordinates of 5336 records $(31.9 \%$ of the total) were not precisely described in source documents, and were thus assigned to the corresponding county seat or state capital. This deficiency often reflects (1) the type of investigation (e.g., necropsy report that identifies collection site only to the county level, regional waterfowl flyway surveys that are summarized by state), (2) the time-consuming nature of determining exact collection sites prior to the advent of handheld GPS units, and in rare instances, (3) hesitancy to report sampling location because of ongoing litigation or the threatened or endangered status of the species being studied.

The CEE-TV database is updated on an annual basis. The sample collection date ranges from 1884 to 2003 . For the 16,360 records for which the sample collection date was specified, the distribution of records among decades is $9.9 \%$ for the $1960 \mathrm{~s}, 30.2 \%$ for the $1970 \mathrm{~s}, 31.0 \%$ for the $1980 \mathrm{~s}$, and $23.3 \%$ for the $1990 \mathrm{~s}$. These findings are in contrast to our earlier report (Rattner et al. 2000) that suggested that sampling of terrestrial vertebrates for ecotoxicological exposure or effects endpoints along the Atlantic and Florida Gulf coast had declined even more markedly since the 1970s.

\section{Phylogenetic Trends}

The database contains information for 483 unique vertebrate species. All of these species spend a significant part of their life on land, with the exception of the sea otter (Enhydra lutris), which was included because it often forages in rocky shallows near shore. Mammals constitute $18.4 \%$ of the records, with representation from eight terrestrial orders found in North America (Table 1). The most consistently studied mammalian orders were Carnivora followed by Rodentia. The only mammalian order occurring in North America without data records is Perissodactyla. Although most of the study regions are dominated by avian data records, ecotoxicological information for mammals in Alaska (47.2\%) approached that of birds (52.8\%). More than two thirds $(77.2 \%)$ of the database records include avian exposure and effects data representing 17 of 21 North American orders of birds. The most common (percent of total database records) avian order in the CEE-TV database is Charadriiformes (19.8\%), followed by Anseriformes (17.9\%), Falconiformes $(9.8 \%)$, Ciconiiformes $(8.7 \%)$, and Passeriformes $(7.5 \%)$. Reptiles constitute $3.8 \%$ of the records, with the majority of records (476 of 678) found below $42^{\circ}$ latitude (generally south of New York, Michigan, and Oregon). Only 104 records in the database $(0.6 \%)$ contained information on amphibians. The paucity of ecotoxicological data in herpe- tofauna is well recognized (Sparling et al. 2000), and despite recent interest in this topic, limited exposure data are available on free-ranging amphibians and reptiles residing in or near estuarine and coastal habitats. Remarkably, we have been unable to find contaminant exposure and effects data for amphibians and reptiles residing in the Pacific coast states and Hawaii. The relative amount of information for various species in the CEE-TV database reflects factors including their abundance and distribution in estuarine and coastal habitat, management status (threatened or endangered), emphasis of various monitoring programs (e.g., waterfowl in the NCBP of the US FWS, and herring gulls, Larus argentatus, in the Canadian Wildlife Service Great Lakes Monitoring Program), ease of sampling, and interspecific sensitivity to various contaminants.

\section{Contaminant Exposure and Effect Endpoints}

Source documents yielded terrestrial vertebrate exposure data for 209 contaminants, most of which have unique Chemical Abstracts Service numbers. These contaminants include 38 organochlorine pesticides and metabolites, 57 other chlorinated hydrocarbons, 37 metals, metalloids, and trace elements, 5 organometallics, 2 shot materials (i.e., lead, steel) used in hunting, 17 petroleum hydrocarbons and mixtures, 18 cholinesterase-inhibiting pesticides, 10 rodenticides, 2 radionuclides, 19 other organic and pharmaceutical compounds, 1 avicide, 1 fungicide, and 2 herbicides (Table 2). Similar to our earlier findings for the Atlantic coast (Rattner et al. 2000), over half of the terrestrial vertebrate exposure records included information on organochlorine pesticides, whereas one-third of the records contained metals exposure data. When measured, quantities of contaminants exceeded the detection limit in over $70 \%$ of the samples; notable exceptions include toxaphene, endrin, carbamate pesticides, barium, beryllium, thallium, and vanadium. Recently, there has been considerable interest in exposure and potential ecological effects of pharmaceuticals, personal care and cleaning products, antimicrobial agents, and other contaminants detected in rivers, lakes, estuaries, and coastal regions in the United States (Hale and La Guardia 2002; Kolpin et al. 2002). Exposure data for such compounds in wildlife are limited (e.g., only $40 \mathrm{CEE}-\mathrm{TV}$ records for polybrominated diphenyl ethers, alkylphenols and ethoxylates, perfluorinated compounds, and pentobarbital). However, it is unclear whether such compounds pose a significant threat to terrestrial vertebrates. In fact, our knowledge of contaminant exposure in wildlife in the United States is based on a small subset of elements and compounds relative to the large number of chemicals in commerce $(>75,000$ including 23,000 polymers that are generally not absorbed in vertebrates; Walker 2003). This subset includes chemicals for which exposure occurs by dietary and dermal routes (Golden and Rattner 2003), are moderately to readily absorbed, bioaccumulate, and are routinely quantified in tissues.

Information on biological effects potentially related to contaminant exposure occurs in $9.3 \%$ of the records in the database. The most frequently measured effect endpoint is eggshell thinning associated with exposure to $p, p^{\prime}$-DDE or other organochlorine pesticides, although the majority of the effect measurements conducted since 1980 involved bio- 
Table 1. Phylogenetic distribution of records in the Contaminant Exposure and Effects - Terrestrial Vertebrates (CEE-TV) database

\begin{tabular}{|c|c|c|c|c|c|c|c|c|c|c|c|c|c|c|c|}
\hline \multirow[b]{2}{*}{ Class } & \multirow[b]{2}{*}{ Order } & \multicolumn{2}{|c|}{$\begin{array}{l}\text { Entire } \\
\text { database }\end{array}$} & \multicolumn{2}{|c|}{$\begin{array}{l}\text { Atlantic } \\
\text { coast }\end{array}$} & \multicolumn{2}{|c|}{ Gulf coast } & \multicolumn{2}{|c|}{$\begin{array}{l}\text { Pacific } \\
\text { coast }\end{array}$} & \multicolumn{2}{|c|}{ Alaska } & \multicolumn{2}{|c|}{ Hawaii } & \multicolumn{2}{|l|}{$\begin{array}{l}\text { Great } \\
\text { Lakes }\end{array}$} \\
\hline & & $n$ & $\%$ & $n$ & $\%$ & $n$ & $\%$ & $n$ & $\%$ & $n$ & $\%$ & $n$ & $\%$ & $n$ & $\%$ \\
\hline \multirow[t]{9}{*}{ Mammalia } & & 3072 & 18.4 & 615 & 12.3 & 234 & 10.1 & 868 & 27.4 & 605 & 47.2 & 33 & 18.3 & 717 & 15.1 \\
\hline & Artiodactyla (even-toed ungulates) & 232 & & 167 & & 18 & & 16 & & 28 & & 0 & & 3 & \\
\hline & Carnivora (true carnivores) & 1941 & & 247 & & 168 & & 756 & & 571 & & 16 & & 183 & \\
\hline & Chiroptera (bats) & 32 & & 32 & & 0 & & 0 & & 0 & & 0 & & 0 & \\
\hline & Didelphimorphia (New World opossums) & 16 & & 16 & & 0 & & 0 & & 0 & & 0 & & 0 & \\
\hline & Insectivora (shrews and moles) & 80 & & 9 & & 0 & & 32 & & 5 & & 0 & & 34 & \\
\hline & Lagomorpha (pikas, rabbits and hares) & 76 & & 3 & & 18 & & 2 & & 0 & & 0 & & 53 & \\
\hline & Rodentia (rodents) & 691 & & 137 & & 30 & & 62 & & 1 & & 17 & & 444 & \\
\hline & Xenarthra (armadillos) & 4 & & 4 & & 0 & & 0 & & 0 & & 0 & & 0 & \\
\hline \multirow[t]{19}{*}{ Aves } & & 12882 & 77.2 & 4084 & 81.5 & 1878 & 81.3 & 2303 & 72.6 & 677 & 52.8 & 142 & 81.1 & 3798 & 80.1 \\
\hline & Anseriformes (waterfowl) & 2988 & & 1033 & & 396 & & 502 & & 242 & & 0 & & 815 & \\
\hline & Apodiformes (swifts) & 1 & & 0 & & 0 & & 0 & & 1 & & 0 & & 0 & \\
\hline & Charadriiformes (shorebirds, gulls, and allies) & 3309 & & 457 & & 350 & & 574 & & 233 & & 31 & & 1664 & \\
\hline & Ciconiiformes (herons, storks, and allies) & 1454 & & 419 & & 421 & & 370 & & 0 & & 0 & & 244 & \\
\hline & Columbiformes (pigeons and doves) & 102 & & 70 & & 14 & & 11 & & 0 & & 1 & & 6 & \\
\hline & Coraciiformes (kingfishers) & 9 & & 3 & & 0 & & 0 & & 0 & & 0 & & 6 & \\
\hline & Cuculiformes (cuckoos) & 8 & & 0 & & 6 & & 0 & & 0 & & 0 & & 2 & \\
\hline & Falconiformes (diurnal birds of prey) & 1631 & & 703 & & 223 & & 258 & & 98 & & 0 & & 349 & \\
\hline & Galliformes (fowl) & 125 & & 16 & & 28 & & 38 & & 20 & & 0 & & 23 & \\
\hline & Gaviiformes (loons) & 360 & & 104 & & 22 & & 39 & & 10 & & 0 & & 185 & \\
\hline & Gruiformes (cranes, rails, and allies) & 335 & & 198 & & 63 & & 71 & & 0 & & 0 & & 3 & \\
\hline & Passeriformes (song birds) & 1255 & & 809 & & 111 & & 98 & & 17 & & 2 & & 218 & \\
\hline & Pelecaniformes (pelicans and allies) & 710 & & 107 & & 150 & & 196 & & 15 & & 8 & & 234 & \\
\hline & Piciformes (woodpeckers and allies) & 14 & & 12 & & 0 & & 2 & & 0 & & 0 & & 0 & \\
\hline & Podicipediformes (grebes) & 97 & & 3 & & 1 & & 73 & & 13 & & 0 & & 7 & \\
\hline & Procellariiformes (albatross, petrels, and allies) & 147 & & 0 & & 0 & & 29 & & 24 & & 94 & & 0 & \\
\hline & Strigiformes (owls) & 300 & & 139 & & 77 & & 35 & & 1 & & 6 & & 42 & \\
\hline & Unspecified & 37 & & 11 & & 16 & & 7 & & 3 & & 0 & & 0 & \\
\hline \multirow[t]{4}{*}{ Reptilia } & & 628 & 3.8 & 277 & 5.5 & 187 & 8.1 & 0 & 0 & 0 & 0 & 0 & 0 & 164 & 3.5 \\
\hline & Crocodylia (alligators) & 166 & & 97 & & 69 & & 0 & & 0 & & 0 & & 0 & \\
\hline & Squamata (lizards) & 83 & & 20 & & 41 & & 0 & & 0 & & 0 & & 22 & \\
\hline & Testudines (turtles) & 379 & & 160 & & 77 & & 0 & & 0 & & 0 & & 142 & \\
\hline \multirow[t]{3}{*}{ Amphibia } & & 104 & 0.6 & 32 & 0.6 & 10 & 0.4 & 0 & 0 & 0 & 0 & 0 & 0 & 62 & 1.3 \\
\hline & Anura (frogs and toads) & 103 & & 31 & & 10 & & 0 & & 0 & & 0 & & 62 & \\
\hline & Caudata (salamanders) & 1 & & 1 & & 0 & & 0 & & 0 & & 0 & & 0 & \\
\hline Unspecified $^{\mathrm{a}}$ & & 10 & & 4 & & 6 & & 0 & & 0 & & 0 & & 0 & \\
\hline
\end{tabular}

${ }^{\text {a }}$ Records including both birds and mammals.

chemical biomarkers (e.g., cholinesterase, cytochrome $\mathrm{P} 450$, DNA damage, measures of oxidative stress, and protoporphyrin).

A number of interesting exposure and effects trends are apparent upon examination of the CEE-TV database. For example, in a retrospective evaluation (1965-1994) of contaminants in osprey (Pandion haliaetus) eggs for the Atlantic coast (Rattner et al. 2000), we reported that $p, p^{\prime}$-DDE concentrations had declined since the 1970s, presumably reflecting restrictions imposed on its use and its degradation in the environment over time. A reanalysis with an expanded dataset for the Atlantic coast from 1965 to 2003 further documented this decline $(p<0.05$; sample size weighted analysis of variance of $\log$ transformed data and Student-Newman-Keuls multiple range test): 1965-1974, geometric mean $p, p^{\prime}-$ $\mathrm{DDE}=3.97 \mu \mathrm{g} / \mathrm{g}$ wet weight, $n=38$ records representing 191 eggs; $1975-1984,2.90 \mu \mathrm{g} / \mathrm{g}, n=17$ records representing 98 eggs; 1985-1994, $1.50 \mu \mathrm{g} / \mathrm{g}, n=9$ records representing 47 eggs; 1995-2003, $0.62 \mu \mathrm{g} / \mathrm{g}, n=8$ records representing 92 eggs. Despite a seemingly downward trend, total PCBs in these same samples did not decline significantly $(p>0.25)$ over time (1965-1974, geometric mean total $\mathrm{PCBs}=5.18 \mu \mathrm{g} / \mathrm{g}$ wet weight; 1975-1984, $6.87 \mu \mathrm{g} / \mathrm{g} ; 1985-1994,4.11 \mu \mathrm{g} / \mathrm{g} ; 1995-$ 2003, $4.70 \mu \mathrm{g} / \mathrm{g})$.

Organophosphorus and carbamate pesticide exposure information (i.e., residues in tissue or digestive tract and/or $\geq 20 \%$ inhibition of brain cholinesterase activity; $n=302$ records) in the CEE-TV database was compared with a retrospective analysis of confirmed and suspected anticholinesterase (antiChE) poisoning events $(n=335)$ (Fleischli et al. 2004) from the National Wildlife Health Center (NWHC) mortality database. There are considerable differences in the scope of these two databases, including diverse information sources in CEE-TV versus analysis of submitted specimens in NWHC mortality database, estuarine and coastal drainages in 30 states, and the District of Columbia versus entire United States, and incidents from 1963 to 2003 versus incidents from 1980 to 2000. Therefore, it is not surprising that only 24 records in the CEE-TV database are in the NWHC mortality database. Anticholinesterase pesticide exposure data in the CEE-TV database include 
Table 2. Frequency of various measurement endpoints in the Contaminant Exposure and Effects-Terrestrial Vertebrates (CEE-TV) database

\begin{tabular}{|c|c|c|c|}
\hline Exposure and effect endpoint & $\begin{array}{l}\text { Number of CEE-TV records } \\
\text { with endpoint examined }\end{array}$ & $\begin{array}{l}\text { Number of CEE-TV records } \\
\text { with detectable concentrations }\end{array}$ & Detection frequency \\
\hline Organochorine pesticides and metabolites & 8051 & & \\
\hline$p, p^{\prime}-\mathrm{DDD} ; p, p^{\prime}-\mathrm{DDE} ; p, p^{\prime}-\mathrm{DDT}$ & 7381 & 7038 & 0.954 \\
\hline Dieldrin & 5093 & 4131 & 0.811 \\
\hline Heptachlor epoxide & 2949 & 2188 & 0.742 \\
\hline Oxychlordane & 2382 & 1922 & 0.807 \\
\hline cis-Chlordane & 1318 & 898 & 0.681 \\
\hline trans-Nonachlor & 1985 & 1530 & 0.771 \\
\hline cis-Nonachlor & 1366 & 1005 & 0.736 \\
\hline Toxaphene & 637 & 201 & 0.316 \\
\hline Hexachlorobenzene & 2335 & 1669 & 0.715 \\
\hline Endrin & 729 & 223 & 0.306 \\
\hline Mirex & 2448 & 1781 & 0.728 \\
\hline Other organochlorine contaminants & 6586 & & \\
\hline Total PCBs (aroclors) & 6287 & 5563 & 0.885 \\
\hline PCB congeners & 689 & 689 & 1.000 \\
\hline Dioxins and dibenzofurans & 639 & 639 & 1.000 \\
\hline Anticholinesterase pesticides & 364 & & \\
\hline Organophosphate & 266 & 199 & 0.748 \\
\hline Carbamate & 180 & 102 & 0.567 \\
\hline Rodenticides & 264 & 260 & 0.985 \\
\hline Avicides & 74 & 60 & 0.811 \\
\hline Metals, metalloids and trace elements & 6051 & & \\
\hline Aluminum & 196 & 168 & 0.857 \\
\hline Arsenic & 731 & 481 & 0.658 \\
\hline Barium & 163 & 89 & 0.546 \\
\hline Beryllium & 152 & 12 & 0.079 \\
\hline Boron & 150 & 103 & 0.687 \\
\hline Cadmium & 1825 & 1461 & 0.801 \\
\hline Chromium & 729 & 626 & 0.859 \\
\hline Copper & 1111 & 1110 & 0.999 \\
\hline Iron & 551 & 550 & 0.998 \\
\hline Lead & 2684 & 2290 & 0.853 \\
\hline Magnesium & 338 & 338 & 1.000 \\
\hline Manganese & 608 & 591 & 0.972 \\
\hline Mercury & 3693 & 3436 & 0.930 \\
\hline Molybdenum & 249 & 180 & 0.723 \\
\hline Nickel & 421 & 324 & 0.770 \\
\hline Selenium & 1111 & 1104 & 0.994 \\
\hline Strontium & 187 & 173 & 0.925 \\
\hline Thallium & 44 & 12 & 0.273 \\
\hline Tin & 40 & 40 & 1.000 \\
\hline Vanadium & 103 & 46 & 0.447 \\
\hline Zinc & 1090 & 1090 & 1.000 \\
\hline Organometallics & 107 & & \\
\hline Monobutyltin & 102 & 81 & 0.794 \\
\hline Dibutyltin & 103 & 98 & 0.951 \\
\hline Tributyltin & 103 & 99 & 0.961 \\
\hline Total butyltin & 56 & 55 & 0.982 \\
\hline Shot used in hunting & 370 & 286 & 0.773 \\
\hline Petroleum hydrocarbons & 899 & & \\
\hline Phenanthrene & 196 & 191 & 0.974 \\
\hline Naphthalene & 203 & 197 & 0.970 \\
\hline Pristane & 210 & 206 & 0.981 \\
\hline Phytane & 273 & 226 & 0.828 \\
\hline Total alkanes & 152 & 152 & 1.000 \\
\hline Total PAHs & 229 & 228 & 0.996 \\
\hline Biomarker/bioindicator effect responses & 1559 & & \\
\hline Aminolevulinic acid dehydratase activity & 25 & & \\
\hline Cholinesterase activity & 451 & & \\
\hline Cytochrome P450 & 96 & & \\
\hline DNA content & 55 & & \\
\hline Eggshell thickness & 727 & & \\
\hline
\end{tabular}


Table 2. Continued

\begin{tabular}{|c|c|c|c|}
\hline Exposure and effect endpoint & $\begin{array}{l}\text { Number of CEE-TV records } \\
\text { with endpoint examined }\end{array}$ & $\begin{array}{l}\text { Number of CEE-TV records } \\
\text { with detectable concentrations }\end{array}$ & Detection frequency \\
\hline Hematological parameters & 134 & & \\
\hline Oxidative stress endpoints & 33 & & \\
\hline Endocrine endpoints & 37 & & \\
\hline Protoporphyrin & 58 & & \\
\hline Sperm morphology & 2 & & \\
\hline
\end{tabular}

58 species of birds and 2 mammals, compared to 103 avian species in the NWHC mortality database. The rank order of antiChE pesticide exposure in the CEE-TV database was Passeriformes $(n=153$ records $)>$ Anseriformes $(n=77)>$ Charadriiformes $(n=29)>$ Falconiformes $(n=22)$, whereas the rank order in the NWHC mortality database was Falconiformes $(n=165)>$ Anseriformes $(n=112)>$ Passeriformes $(n=79)>$ Columbiformes $(n=18)$. The differences are probably due, at least in part, to differences in the geographic scope of these databases. Diazinon, carbofuran, parathion, and monocrotophos were the most common antiChE pesticides in the CEE-TV database, whereas famphur, carbofuran, diazinon, and fenthion were most prevalent in the NWHC mortality database. Anticholinesterase pesticide exposure records in the CEE-TV database have increased steadily over time (before 1970, 2 records; 1970-1979, 28 records; 1980-1989, 52 records; 1990-2003, 220 records), presumably reflecting both increased use of these pesticides, and also perhaps more efficient detection and reporting of exposure and die-off events.

Of 3600 records containing information on mercury exposure, only 6 included information regarding adverse effects (i.e., possible mercury poisoning). More than half of all mercury records contained information for fish-eating birds ( $n=1942)$, with the herring gull $(n=339)$, common loon (Gavia immer, $n=214$ ), and bald eagle (Haliaeetus leucocephalus, $n=196$ ) accounting for more data than any other individual species. No temporal trends were found for mercury in eggs of fish-eating birds, although regional differences were apparent. For the continental United States, the geometric mean concentration in eggs collected from the Atlantic Coast $(0.39 \mu \mathrm{g} / \mathrm{g}$ wet weight, $n=141$ records representing 986 eggs) was higher $(p<0.05$; sample size weighted analysis of variance of $\log$ transformed data and Student-Newman-Keuls multiple range test) than concentrations in eggs collected from the Pacific Coast $(0.29 \mu \mathrm{g} / \mathrm{g}$, $n=39$ records representing 451 eggs) and Gulf Coast $(0.24$ $\mu \mathrm{g} / \mathrm{g}, n=65$ records representing 309 eggs), but did not differ from that of the Great Lakes $(0.32 \mu \mathrm{g} / \mathrm{g}, n=431 \mathrm{re}-$ cords representing 3421 eggs). This trend is generally consistent with both the US EPA's reporting of higher mercury emissions in the eastern United States and recent findings of increasing blood mercury concentrations in loons as collection sites ranged from west to east (US EPA 1997b; Evers et al. 1998). For fish-eating birds in Florida, mean mercury concentrations in eggs $(0.18 \mu \mathrm{g} / \mathrm{g})$ were lower than regional averages, after the removal of one atypically high data point (7.93 $\mu \mathrm{g} / \mathrm{g}$ in 12 sooty tern, Sterna fuscata, eggs from the Dry Tortugas). However, mercury concentrations in feathers, at or exceeding levels associated with adverse effects $(5 \mu \mathrm{g} / \mathrm{g}$ dry weight; Eisler 2000), were found in a greater percentage of birds in Florida $(50 \%, n=35$ of 71 records) than all other states combined ( $15 \%, n=13$ of 88 records).

\section{Spatial Trends}

Records in the CEE-TV database from estuarine and coastal habitats are distributed among 30 states and the District of Columbia (Fig. 1). States with the largest number of records include California (2202), New York (1774), Florida (1498), Alaska (1282), and Texas (1065). The District of Columbia contained the fewest number of records (2) followed by Rhode Island (43), New Hampshire (44), Alabama and Indiana (46), and Mississippi (59). However, this ranking changes when the 7306 records with known coordinates that fall in estuarine and coastal drainages in the continental United States are examined. The greatest density of records in estuarine and coastal drainages include the states of Georgia, New York, New Jersey, South Carolina, and California (0.013-0.010 records/ $\mathrm{km}^{2}$ ), whereas the lowest densities of records were found in Alabama, the District of Columbia, Minnesota, New Hampshire, and Illinois (0.00006-0.0013 records $\left./ \mathrm{km}^{2}\right)$.

Of the 464 coastal watersheds in the United States, CEE-TV data records were found in $270(58.1 \%)$. The 10 largest watersheds (or portions thereof defined by a single hydrologic unit code) without recent (1990-2003) exposure and effects data in terrestrial vertebrates are presented in Table 3 . It is important to note that this analysis is limited to the continental United States, because coastal watersheds in Alaska and Hawaii have not been assigned hydrologic unit codes. Based on the IWI, 96 of these watersheds were classified as having serious water quality problems, 53 were considered to be highly vulnerable to pollution, and 16 had both serious water quality problems and high vulnerability to pollution. Of these 165 watersheds of concern, $72(43.6 \%)$ lacked recent (since 1990) terrestrial vertebrate ecotoxicological data. The watersheds that lack recent data but have both serious water quality problems and high vulnerability to pollution (Table 3 ) should receive priority for terrestrial vertebrate contaminant monitoring studies.

Because of their significance from a wildlife management perspective, an information gap analysis was conducted for units of the National Wildlife Refuge System and the National Park System in the geographic area encompassed by the CEETV database. Attempts were made to verify the findings by contacting staff at each management unit. Of 216 National Wildlife Refuges in the study area, data were available for terrestrial vertebrates at or within $10 \mathrm{~km}$ (to account for animal movement) of 150 refuges $(69.4 \%)$, and recent data (1990- 


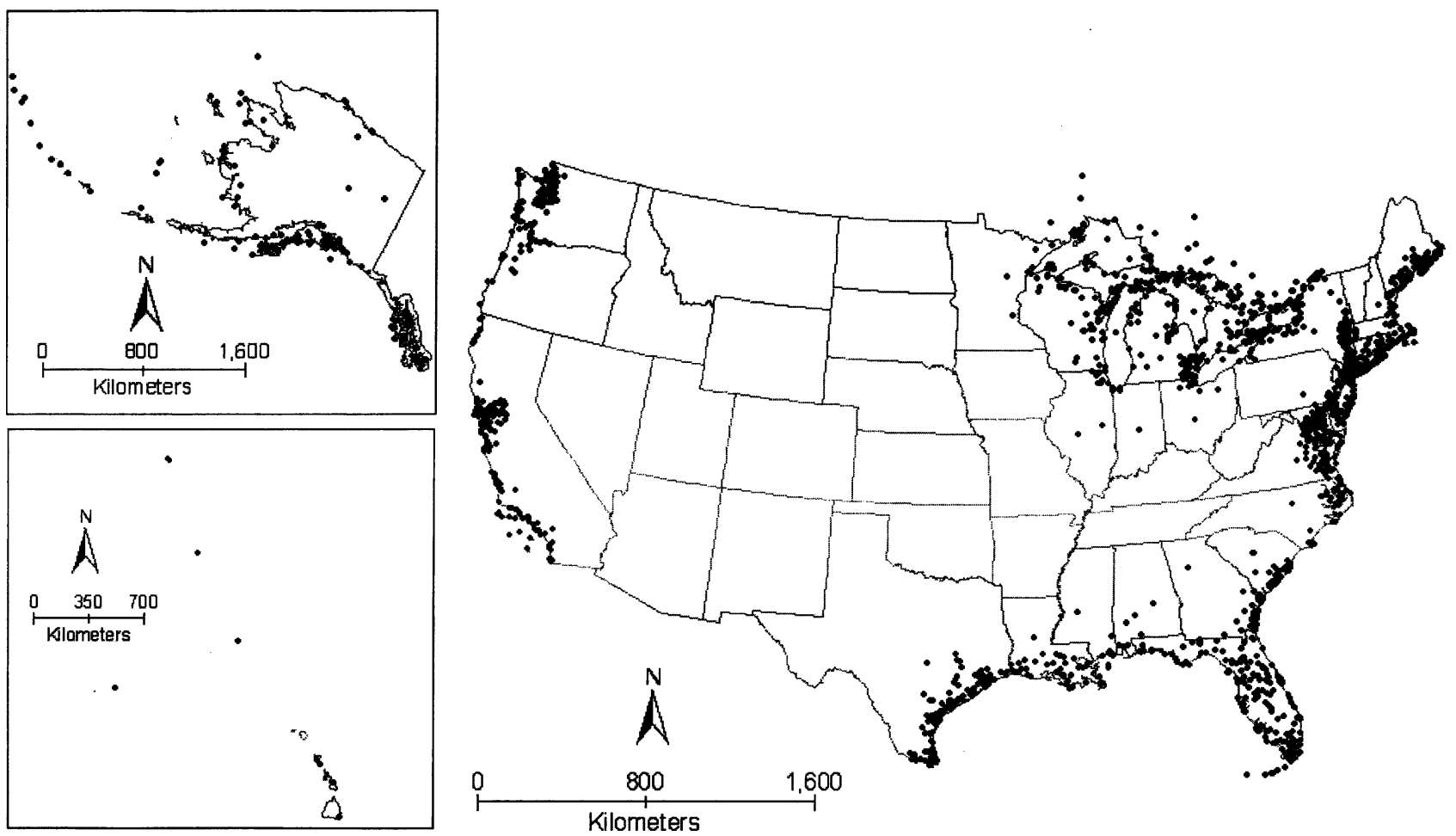

Fig. 1. Geographic distribution of CEE-TV database records along the Atlantic coast $(n=4977)$, Gulf coast (2345), Pacific coast (3171), Great Lakes (4746), Alaska (1282), and Hawaii (175). Note that many records share a common location, particularly in Hawaii.

Table 3. Estuarine and coastal drainages of the continental United States lacking recent (1990-2003) Contaminant Exposure and EffectsTerrestrial Vertebrates (CEE-TV) data

\begin{tabular}{|c|c|c|c|}
\hline Watershed & State & Hydrologic unit code & Area $\left(\mathrm{km}^{2}\right)$ \\
\hline \multicolumn{4}{|c|}{ Largest watersheds or portion of watersheds lacking recent data } \\
\hline Big Navarro-Garcia & $\mathrm{CA}$ & 18010108 & 6434 \\
\hline Suwannee River & FL & 03110102 & 5575 \\
\hline Queets-Quinault & WA & 17100102 & 4398 \\
\hline Narragansett Bay & $\mathrm{RI} / \mathrm{MA}$ & 01090004 & 4346 \\
\hline New River & $\mathrm{NC}$ & 03030001 & 3979 \\
\hline Sabine Lake & $\mathrm{TX}$ & 12040201 & 3885 \\
\hline Sixes & OR & 17100306 & 3751 \\
\hline Northwestern Lake Superior & $\mathrm{MN}$ & 04010101 & 3711 \\
\hline Eastern Lower Delmarva & MD/VA & 02080110 & 3639 \\
\hline Monterey Bay & $\mathrm{CA}$ & 18060005 & 3485 \\
\hline \multicolumn{4}{|c|}{ Watersheds with "more serious water quality problems" and "high vulnerability to pollution" lacking recent data } \\
\hline Middle Delaware River & $\mathrm{PA} / \mathrm{NJ}$ & 02040201 & 2485 \\
\hline Atchafalaya/Vermilion Bays & LA & 08080102 & 1348 \\
\hline Western Mississippi Sound & LA & 08070202 & 777 \\
\hline Central San Francisco/San Pablo/Suisin Bays & $\mathrm{CA}$ & 18020111 & 532 \\
\hline Central San Francisco/San Pablo/Suisun Bays & $\mathrm{CA}$ & 18040002 & 471 \\
\hline
\end{tabular}

2003) were available for $107(49.5 \%)$ refuges. Of the 126 National Park units in the study area, data were available at or near $80(63.5 \%)$ of the units (10-km boundary), and recent data (1990-2003) were available at $66(52.4 \%)$. It is peculiar that only 8 of 31 National Wildlife Refuge and National Park units in Alaska and only 3 of 23 such management units in Hawaii have terrestrial vertebrate contaminant data. The 10 largest management units in coastal habitat of the continental United States that lack recent terrestrial vertebrate contaminant data are presented in Table 4 . The boundary maps of these management units were overlaid on the watershed map, and those that intersected watersheds of concern were placed into a separate map for further analysis. The plot of the CEE-TV records was overlaid on maps of watersheds and management 
Table 4. National Wildlife Refuge and National Park units in coastal and estuarine drainages of the continental United States lacking recent (1990-2003) Contaminant Exposure and Effects-Terrestrial Vertebrates (CEE-TV) data

\begin{tabular}{|c|c|c|}
\hline Management unit name & State & $\begin{array}{l}\text { Refuge and park unit } \\
\text { area including buffer }\left(\mathrm{km}^{2}\right)\end{array}$ \\
\hline \multicolumn{3}{|c|}{ Largest National Wildlife Refuge (NWR) units lacking data ${ }^{a}$} \\
\hline Lower Suwannee NWR & FL & 1605.6 \\
\hline Seney NWR & MI & 1529.1 \\
\hline Bon Secour NWR & LA & 1370.1 \\
\hline Hobe Sound NWR & FL & 1326.6 \\
\hline Copalis NWR & WA & 1178.1 \\
\hline Big Branch Marsh NWR & LA & 1171 \\
\hline Montezuma NWR & NY & 1078.1 \\
\hline McFaddin NWR & TX & 1061.0 \\
\hline Erie NWR & PA & 1024.0 \\
\hline Grand Bay NWR & $\mathrm{AL}$ & 712.9 \\
\hline \multicolumn{3}{|l|}{ Largest National Park units lacking data ${ }^{\mathrm{a}}$} \\
\hline Sleeping Bear Dunes National Lakeshore & MI & 2524.3 \\
\hline Petersburg National Battlefield & VA & 922.7 \\
\hline Minute Man National Historic Park & MA & 437.9 \\
\hline Grand Portage National Monument & $\mathrm{MN}$ & 597.5 \\
\hline George Washington Birthplace National Monument & VA & 390.5 \\
\hline Fort Matanzas National Monument & FL & 373.0 \\
\hline Cuyahoga Valley National Park & $\mathrm{OH}$ & 977.9 \\
\hline Canaveral National Seashore & FL & 1485.6 \\
\hline Biscayne National Park & FL & 990.7 \\
\hline Big Thicket National Preserve & $\mathrm{TX}$ & 957.8 \\
\hline \multicolumn{3}{|c|}{ Units in watersheds with "more serious water quality problems" and "high vulnerability to pollution" lacking datab } \\
\hline Brazoria NWR & TX & 288.7 \\
\hline Bayou Teche NWR & LA & 233.6 \\
\hline Minute Man National Historic Park & MA & 28.0 \\
\hline John Muir National Historic Site & CA & 18.7 \\
\hline Presidio National Park & CA & 18.3 \\
\hline Muir Woods National Monument & CA & 13.5 \\
\hline Boston National Historic Park & MA & 11.2 \\
\hline Statue of Liberty National Monument & NY & 7.0 \\
\hline Boston African-American National Historic Site & MA & 6.6 \\
\hline Edison National Historic Site & NJ & 5.2 \\
\hline
\end{tabular}

${ }^{a}$ Area including 10-km buffer.

${ }^{\mathrm{b}}$ Units $>5 \mathrm{~km}$ including $1-\mathrm{km}$ buffer.

units. To identify significant data gaps, ArcGIS was used to map CEE-TV data collected from 1990 to 2003. A total of 76 National Wildlife Refuges and 59 National Park units that lack recent data fell in, or within one kilometer, of watersheds of concern. However, only 18 of these management units were located in watersheds that the IWI classifies as having both "more serious water quality problems" and "high vulnerability to pollution" (Table 4).

\section{Conclusion}

It is recognized that these analyses have potential sources of bias and inaccuracy. For example, although most of the published data were acquired, undoubtedly not all of the unpublished data were obtained. Some collection locations were either not reported in the literature or locations were inaccurate, making it difficult to evaluate individual sites. Finally, although most documents were peer reviewed, there are always concerns about comparability of analytical results.
Nonetheless, the findings of our analyses reveal some trends that deserve attention. Despite widespread concerns about environmental pollution, we found that during the past decade only about one-half of the coastal National Wildlife Refuge and National Park units appear to have terrestrial vertebrate ecotoxicological data. In addition, a significant number of these units (76 National Wildlife Refuge and 59 National Park units representing about 20,000 $\mathrm{km}^{2}$ ) fall within watersheds of concern. Based upon known water quality problems and vulnerability to pollution, we identified a preliminary list of U.S. Department of the Interior management units where terrestrial vertebrate ecotoxicology monitoring appears to be most warranted. In order to best assess large-scale terrestrial vertebrate ecotoxicological trends in the United States, a monitoring program that incorporates some form of random sampling is warranted, in addition to spatial and temporal replication. At a minimum, a regionalized program or efforts focused on lands in watersheds of concern might help detect effects in localized areas and prevent serious natural resource problems. 
Acknowledgments. We thank Lynda J. Garret, Wanda Manning, and Kathryn A. Mannstedt for assistance with the computerized literature searches and data retrieval; Craig R. Beckman, Eileen K. Henniger, Rebecca L. Kershnar, Elise A. Larsen, Katie L. Lobner, Anne M. Meckstroth, and Craig W. Meeusen for compiling and coding database records; and Jonathan B. Cohen and James J. Coyle for reviewing a draft of this manuscript.

\section{References}

BEST (Biomonitoring of Environmental Status and Trends Program) (2003) http://www.best.usgs.gov

Breckenridge RP, Manguba M, Anderson PJ, Bartish TM (2003) Using biomonitoring data for stewardship of natural resources. In: Hoffman DJ, Rattner BA, Burton GA Jr, Cairns J Jr (eds) Handbook of ecotoxicology. 2nd ed. Lewis Publishers, Boca Raton, Florida, pp 233-255

Cohen JB, Rattner BA, Golden NH (2003) Use of retrospective data to assess ecotoxicological monitoring needs for terrestrial vertebrates residing in Atlantic coast estuaries. Ecotoxicology 12:365375

Eisler R (2000) Handbook of chemical risk assessment: Health hazards to humans, plants, and animals. Volume 1. Metals. Lewis Publishers, Boca Raton, Florida, pp 313-409

Evers DC, Kaplan JD, Meyer MW, Reaman PS, Braselton WE, Major A, Burgess N, Scheuhammer AM (1998) Geographic trend in mercury measured in common loon feathers and blood. Eviron Toxicol Chem 17:173-183

Fleischli MA, Franson JC, Thomas NJ, Finley DL, Riley W Jr (2004) Avian mortality events in the United States caused by anticholinesterase pesticides: A retrospective summary of National Wildlife Health Center records from 1980 to 2000. Arch Environ Contam Toxicol 46:542-550

Golden NH, Rattner BA (2003) Ranking terrestrial vertebrate species for utility in biomonitoring and vulnerability to environmental contaminants. Rev Environ Contam Toxicol 176:67136

Hale RC, La Guardia MJ (2002) Emerging contaminants of concern in coastal and estuarine environments. In: Newman MC, Roberts MH Jr, Hale RC (eds) Coastal and estuarine risk assessment. Lewis Publishers, Boca Raton, Florida, pp 41-72
Kolpin DW, Furlong ET, Meyer MT, Thurman EM, Zaugg SD, Barber LB, Buxton HT (2002) Pharmaceuticals, hormones, and other organic wastewater contaminants in U.S. streams, 19992000: A national reconnaissance. Environ Sci Technol 36:12021211

NRC (National Research Council) (1995) A review of the Biomonitoring of Environmental Status and Trends program: The draft detailed plan. National Research Council. National Academy Press, Washington, DC, 74 pp

Rattner BA, Pearson JL, Golden NH, Cohen JB, Erwin RM, Ottinger MA (2000) Contaminant exposure and effects-terrestrial vertebrates database: trends and data gaps for Atlantic Coast estuaries. Environ Monit Assess 63:131-142

Russom CL (2002) Mining environmental toxicology information: Web resources. Toxicology 173:75-88

Schmitt CJ, Bunck CM (1995) Persistent environmental contaminants in fish and wildlife. In: LaRoe ET, Farris GS, Puckett CE, Doran PD, Mac MJ (eds) Our living resources. U.S. Department of the Interior, National Biological Service, Washington, DC, pp 413-416

Sparling DW, Bishop CA, Linder G (2000) The current status of amphibian and reptile ecotoxicological research. In: Sparling DW, Bishop CA, Linder G (eds) Ecotoxicology of amphibians and reptiles. SETAC Press, Pensacola, Florida, pp 1-13

US EPA (U.S. Environmental Protection Agency) (1997a) The index of watershed indicators. EPA-841-R-97-010. United States Environmental Protection Agency, Office of Water, Washington, DC

US EPA (U.S. Environmental Protection Agency) (1997b) Mercury study report to Congress, Vol. 2. An inventory of anthropogenic mercury emissions in the United States. EPA-452/R-97-004. United States Environmental Protection Agency, Office of Air Quality Planning \& Standards and Office of Research and Development, Washington, DC

US EPA (U.S. Environmental Protection Agency) (2000) Environmental Monitoring and Assessment Home Page (EMAP). World Wide Web site, http://www.epa.gov/emap

Walker JD (2003) QSARs for toxicity screening-current practices. In: Walker JD (eds) Quantitative structure-activity relationships for pollution prevention, toxicity screening, risk assessment, and Web applications. SETAC Press, Pensacola, Florida, pp $39-74$

Zylstra SJ (1994) A new program for biomonitoring status and trends in the environment. J Aquat Ecosyst Health 3:81-85 